\title{
Relaxant effect of the aqueous extract of Erythrina vellutina leaves on rat vas deferens
}

\author{
Márcio R. V. Santos ${ }^{1}$, Péricles B. Alves ${ }^{2}$, Angelo R. Antoniolli ${ }^{1}$, Murilo Marchioro ${ }^{1 *}$ \\ ${ }^{1}$ Laboratório de Farmacologia, Departamento de Fisiologia, Universidade Federal de Sergipe; 49100-000, São \\ Cristóvão, SE, Brazil, \\ ${ }^{2}$ Laboratório de Pesquisa de Produtos Naturais, Departamento de Química, Universidade Federal de Sergipe, \\ 49100-000, São Cristóvão, SE, Brazil
}

\begin{abstract}
RESUMO: "Efeito relaxante do extrato aquoso das folhas de Erythrina vellutina em ducto deferente de rato". O objetivo deste trabalho foi avaliar o efeito do extrato aquoso das folhas de Erythrina vellutina (AE) sobre ducto deferente de rato. Nesta preparação, o AE inibiu as contrações induzidas por estímulo elétrico de campo de maneira dependente da concentração. Esta inibição não foi afetada após atropina $\left(10^{-5} \mathrm{M}\right)$, propanolol $\left(10^{-5} \mathrm{M}\right)$, prazosin $\left(10^{-5} \mathrm{M}\right)$ ou yohimbina $\left(10^{-5} \mathrm{M}\right)$, sugerindo uma ação indireta do $\mathrm{AE}$ sobre receptores colinérgicos ou adrenérgicos. A incubação da preparação com os antagonistas de canais de $\mathrm{K}^{+}$, tetraetilâmonio $\left(10^{-6} \mathrm{M}\right)$ ou 4-aminopiridina $\left(10^{-6} \mathrm{M}\right)$ não alterou o efeito inibitório induzido pelo AE. Entretanto, a glibenclamida $\left(10^{-6} \mathrm{M}\right)$ atenuou significantemente este efeito, sugerindo um possível envolvimento de canais de $\mathrm{K}^{+}$dependentes de ATP. Além disso, o AE $(0.15 \mathrm{mg} / \mathrm{mL})$ não alterou as contrações induzidas por noradrenalina $\left(10^{-5} \mathrm{M}\right)$, ATP $\left(10^{-4} \mathrm{M}\right)$ ou $\mathrm{KCl}(80 \mathrm{mM})$, descartando uma interação do AE com um sítio pós-sináptico. Em conclusão, estes resultados demonstram que o efeito inibitório do AE pode ser devido a uma interação pré-sináptica com canais de $\mathrm{K}^{+}$dependentes de ATP em neurônios simpáticos de ducto deferente de rato.
\end{abstract}

Unitermos: Erythrina vellutina, ducto deferente de rato, canal de $\mathrm{K}^{+}$dependente de ATP.

\begin{abstract}
The effect of the Aqueous Extract from the leaves of Erythrina vellutina (AE) on rat vas deferens preparation was evaluated in this work. The AE inhibited the muscle contractions induced by electrical field stimulation (EFS) in a concentration-dependent manner. This inhibition was not affected by atropine $\left(10^{-5} \mathrm{M}\right)$, propanolol $\left(10^{-5} \mathrm{M}\right)$, prazosin $\left(10^{-5} \mathrm{M}\right)$ or yohimbine $\left(10^{-}\right.$ ${ }^{5} \mathrm{M}$ ), suggesting that there is no direct interaction of the AE with cholinergic nor adrenergic receptors. Incubation of vas deferens with the $\mathrm{K}^{+}$channel antagonists, tetraethylamonium $\left(10^{-}\right.$ $\left.{ }^{6} \mathrm{M}\right)$ or 4 -aminopyridine $\left(10^{-6} \mathrm{M}\right)$ had also no effect on the AE-induced inhibition. On the other hand, glibenclamide $\left(10^{-6}\right)$ significantly attenuated the effect of the $\mathrm{AE}$, suggesting a possible involvement of ATP-dependent $\mathrm{K}^{+}$channels. The AE $(0.15 \mathrm{mg} / \mathrm{mL})$ did not alter the contractions induced by noradrenaline $\left(10^{-5} \mathrm{M}\right)$, ATP $\left(10^{-4} \mathrm{M}\right)$ nor $\mathrm{KCl}(80 \mathrm{mM})$, against an interaction of the extract with post-synaptic sites. The data presented suggests that the inhibition of the electrically driven muscle twitches by the $\mathrm{AE}$ could be due to a pre-synaptic interaction of the extract with ATP-dependent $\mathrm{K}^{+}$channels from vas deferens sympathetic neurons.
\end{abstract}

Keywords: Erythrina vellutina, rat vas deferens, ATP-dependent $\mathrm{K}^{+}$channel.

\section{INTRODUCTION}

The genus Erythrina (Leguminosae) Milld, with at least 110 species identified (Vasconcelos et al., 2003), has attracted the attention of many scientists, probably because some of the Erythrina species have been used in folk medicine from South and North America (GarínAguilar et al., 2000) to Africa (El-Olemy et al., 1983) and Asia (Telikepalli et al., 1990; Kòbaiashi et al., 1997; Hegde et al., 1997). In Brazilian folk medicine, different species of Erythrina are used for the treatment of central nervous system (CNS) diseases such as nervous system excitation, insomnia, convulsions and nervous coughs
(Teske; Trentini, 1995; Matos, 1997; Agra et al., 2007). Despite previous studies have demonstrated that extracts of E. velutina possesse effects on the CNS (Dantas et al., 2004, Vasconcelos et al., 2004, Ribeiro et al., 2006) and antibacterial (Virtuoso et al., 2005), its mechanism of action still remain unclear.

The rat vas deferens preparation is a classical model for the study of substances that interfere with the mechanisms of cholinergic, noradrenergic and purinergic neurotransmission. Knoll et al. (1972) showed that acetylcholine is released in a frequencydependent manner and that it interacts with muscarinic receptors to promote muscle contraction. It also binds 
to nicotinic receptors from adrenergic varicosities resulting in noradrenaline release (Carneiro; Markus, 1990). Noradrenaline appears to be the main transmitter in rat vas deferens and its effects are abolished by $\alpha$ adrenergic but not by $\beta$-adrenergic antagonists (Brown et al., 1983). There are also strong evidences for the participation of a non-cholinergic and non-adrenergic neurotransmitter in rat vas deferens (Sneddon et al., 1982; Sneddon; Burnstock, 1984). ATP appears to be one of the transmitters since it was demonstrated in this preparation a P2 receptor-dependent effect (Sneddon et al., 1982).

In this work we used the rat vas deferens preparation to evaluate the effects of the aqueous extract from the leaves of Erythrina vellutina on the peripheral nervous system.

\section{MATERIAL AND METHODS}

\section{Animals}

Male Wistar rats (200-300 g) were used in all experiments. Animals were housed in temperature of 25 $\pm 1{ }^{\circ} \mathrm{C}$, clear/dark cycle of $12 / 12$ hours, feeding with PURINE and water ad libtum. All procedures described in the present work are in agreement with the rules of the Animal Research Ethics Committee of Universidade Federal de Sergipe (UFS).

\section{Plant material}

Erythrina vellutina leaves were collected on the campus of the UFS, at Aracaju-SE, Brazil, and a voucher specimen was deposited at the University herbarium under the number ASE 4126. The leaves were dried at $40{ }^{\circ} \mathrm{C}$ until complete dehydration, and then triturated in a blender until a finely granulated powder was obtained. The aqueous extract was obtained from this powder by adding distilled water $(1: 10, \mathrm{w} / \mathrm{v})$ for $30 \mathrm{~min}$ at $100{ }^{\circ} \mathrm{C}$. After filtration, the extract was lyophilized and stored at $5{ }^{\circ} \mathrm{C}$ for later use. For the pharmacological experiments, the lyophilised extract was diluted at a concentration of $50 \mathrm{mg} / \mathrm{mL}$.

\section{Tissue preparation}

The animals were sacrificed by cervical dislocation and the vas deferentia were removed by a medial incision in the abdominal cavity. After being removed they were dissected further to remove the excess of adipose tissue. 10 to $12 \mathrm{~mm}$ segments were suspended by a platinum electrode on a heated $\left(37^{\circ} \mathrm{C}\right)$ $10 \mathrm{~mL}$ organ bath, in a Krebs solution (containing in mM: $\mathrm{NaCl}, 118 ; \mathrm{KCl}, 4.6 ; \mathrm{CaCl}_{2} 2 \mathrm{H}_{2} \mathrm{O}, 2.9 ; \mathrm{KH}_{2} \mathrm{PO}_{4}$, 1.17; $\mathrm{MgCl}_{2} 6 \mathrm{H}_{2} \mathrm{O}, 1.31 ; \mathrm{NaHCO}_{3}, 25$, Glucose, 11.1), bubbled with an mixture of $95 \% \mathrm{O}_{2}$ and $5 \% \mathrm{CO}_{2}$. The isometric contractions were recorded with a Gould force transducer under a resting tension of $1 \mathrm{~g}$. Tissues were equilibrated for at least 60 min with bath solution changes every $15 \mathrm{~min}$.

\section{Experiments involving electrical field stimulation}

After equilibrium was achieved, vas deferens segments were submitted to a continuous electrical field stimulation (EFS) $(0.15 \mathrm{~Hz}, 1 \mathrm{~ms}$, supramaximum voltage).Cumulative concentration-response curves were obtained with the addition of different concentrations of the $\mathrm{AE}(0.05,0.15,0.5$ and $1.5 \mathrm{mg} / \mathrm{mL})$ and pinacidil (PIN) $\left(10^{-8}\right.$ to $\left.3.10^{-6} \mathrm{M}\right)$, during the electrical stimulation, in the absence and presence of glibenclamide (GLIB) $\left(10^{-6} \mathrm{M}\right)$. In other set of experiments, $\mathrm{AE}$ was added to bath in a single dose $(0.15 \mathrm{mg} / \mathrm{mL})$ and its relaxant effect was compared before and after incubation for 20 min with atropine (ATR) $\left(10^{-5} \mathrm{M}\right)$, propranolol (PRP) $\left(10^{-5} \mathrm{M}\right)$, prazosin (PZS) $\left(10^{-5} \mathrm{M}\right)$, yohimbine (YHB) $\left(10^{-}\right.$ $\left.{ }^{5} \mathrm{M}\right)$, glibenclamide (GLIB) $\left(10^{-6} \mathrm{M}\right)$, 4-aminopyridine (4-AP) $\left(10^{-6} \mathrm{M}\right)$, tetraethylamonium (TEA) $\left(10^{-6} \mathrm{M}\right)$ or dimetilsulfoxide (DMSO), separately. The dose of 0.15 $\mathrm{mg} / \mathrm{mL}$ of the $\mathrm{AE}$ was chosen for these experimental protocols because it was the dose able in induced $50 \%$ of inhibitory effect.

\section{Experiments involving exogenous applied drugs}

The responses of the vas deferens were evaluated for noradrenaline (NA) $\left(10^{-5} \mathrm{M}\right)$, ATP $\left(10^{-4} \mathrm{M}\right)$ and $\mathrm{KCl}(80 \mathrm{mM})$ in the absence and presence of the AE. After two similar and consecutive responses were obtained, the preparation was incubated with $0.15 \mathrm{mg} /$ $\mathrm{mL}$ of the AE $20 \mathrm{~min}$ before recording a new response.

\section{Drugs}

Pinacidil, prazosin, propanolol, yohimbine, tetarethylamonium and glibenclamide were purchased from RBI. Noradrenaline and 4-aminopyridine were from SIGMA and atropine was purchased from MERK. Pinacidil and glibenclamide were diluted in DMSO (final concentration in organ bath: $0.1 \%$ ), while other drugs were diluted in distilled water.

\section{Statistical analysis}

The results are presented as mean \pm s. e. mean and were analysed by the Graph Pad Prism program 3.02. The differences were estimated by the Student's $t$ test for comparison of two means, with the level of significance set at $\mathrm{p}<0.05$.

\section{RESULTS AND DISCUSSION}

As showed in Figure 1, addition of the AE to the preparation reduced the contractions induced 
by EFS in a concentration-dependent manner. At increasing concentrations $(0.05-1.5 \mathrm{mg} / \mathrm{mL})$ the $\mathrm{AE}$ practically abolished the contractions induced by the electrical stimulation. This effect was reversed, after 5 min of washing, demonstrated a possible absence of desensitisation (Figure 1).

One hypothesis to explain the inhibitory effects of the AE would be an interaction with cholinergic or noradrenergic receptors from vas deferens sympathetic neurons. The preparation was then incubated with AE
$(0.15 \mathrm{mg} / \mathrm{mL})$, in the presence of atropine $\left(10^{-5} \mathrm{M}\right)$, a cholinergic muscarinic antagonist, propanolol $\left(10^{-5} \mathrm{M}\right)$, a non-selective $\beta$-adrenergic antagonist, prazosin (10$\left.{ }^{5} \mathrm{M}\right)$, a $\alpha_{1}$-adrenergic antagonist or yohimbine $\left(10^{-5} \mathrm{M}\right)$, a $\alpha_{2}$-adrenergic antagonist, separately. As illustrated in Figure 2A none of the antagonists tested interfered with the AE inhibition of vas deferens contraction $(p<0.05$, $n=6$ ), suggesting that there is no direct interaction of the extract with cholinergic or adrenergic receptors.

In the next step to evaluate a possible
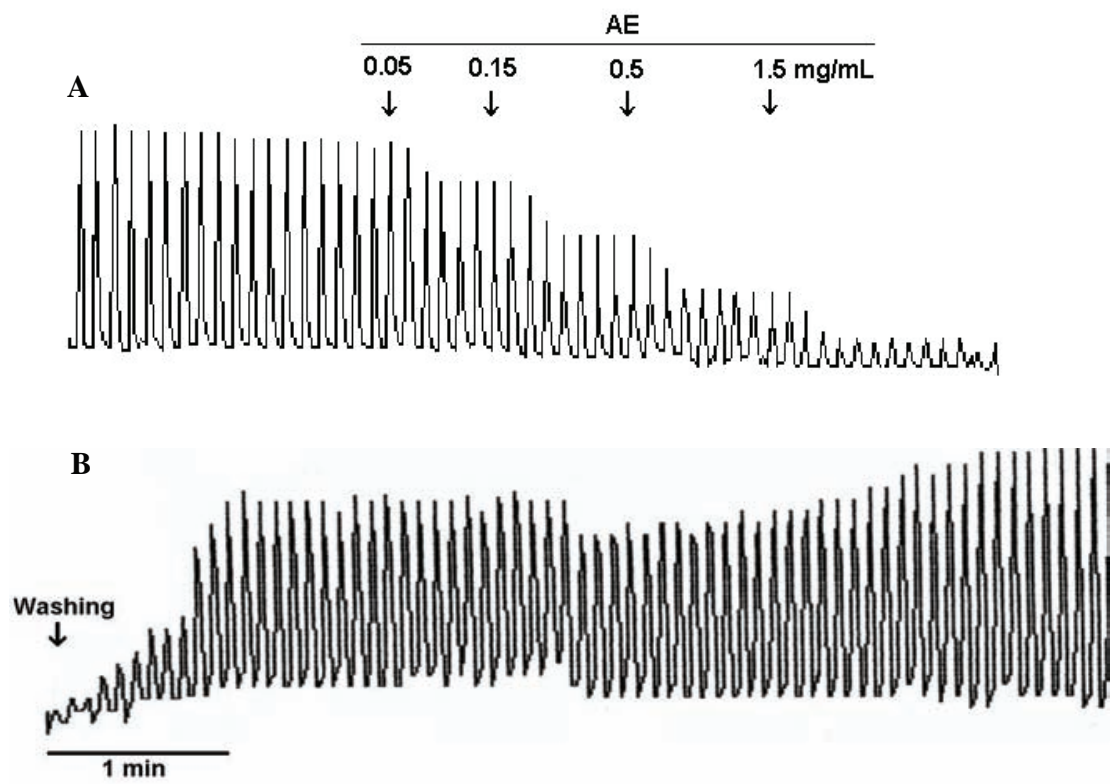

Figure 1. Original traces of: A - Concentration-response curve showing the effect of the aqueous extract of E. vellutina (AE) $(0.05,0.15,0.5$ and $1.5 \mathrm{mg} / \mathrm{mL})$ on the electrical field stimulation induced contractions of the rat vas deferens and B - the full recovery to the basal contractions after washing.
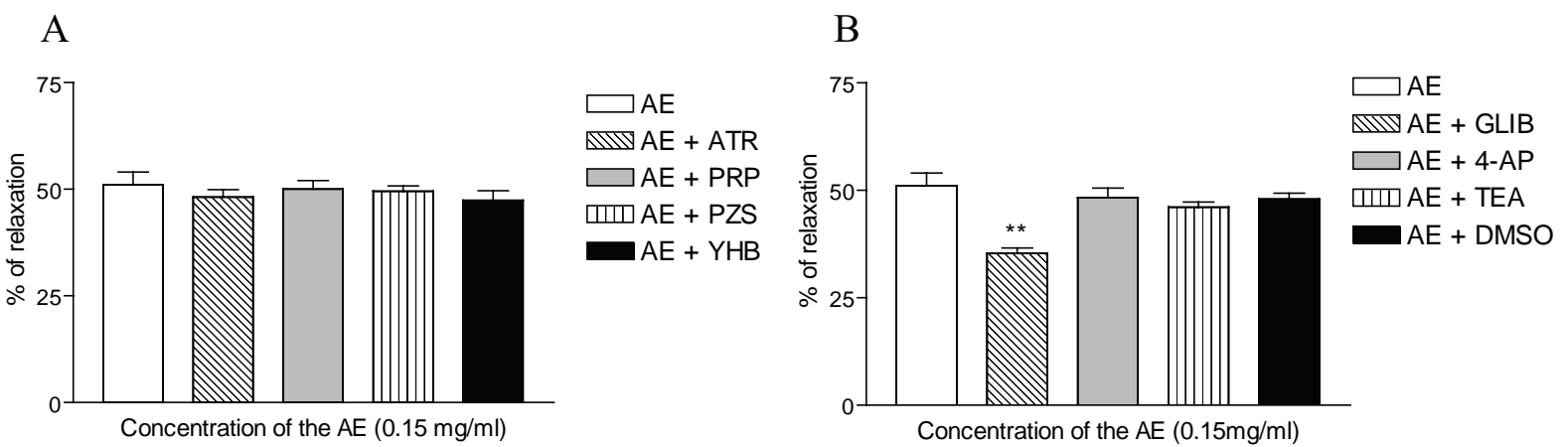

Figure 2. Effects of: (A) - atropine (ATR) $\left(10^{-5} \mathrm{M}\right)$, propanolol (PRP) $\left(10^{-5} \mathrm{M}\right)$, prazosin (PZS) $\left(10^{-5} \mathrm{M}\right)$ and yohimbine (YHB) $\left(10^{-}\right.$ ${ }^{5} \mathrm{M}$ ) and (B) - glibenclamide (GLIB) $\left(10^{-6} \mathrm{M}\right)$, 4-aminopyridine (4-AP) $\left(10^{-6} \mathrm{M}\right)$, tetraethylamonium (TEA) $\left(10^{-6} \mathrm{M}\right)$ and DMSO on the relaxation induced by the aqueous extract of E. vellutina $(\mathrm{AE})(0.15 \mathrm{mg} / \mathrm{mL})$ on the rat vas deferens. The values are expressed as mean \pm s.e.mean of six experiments. ${ }^{* *} \mathrm{p}<0.01$ vs AE. 
A

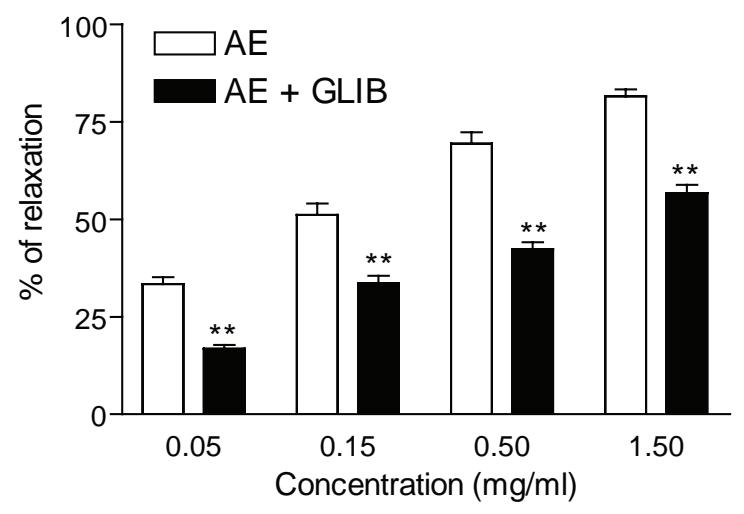

B

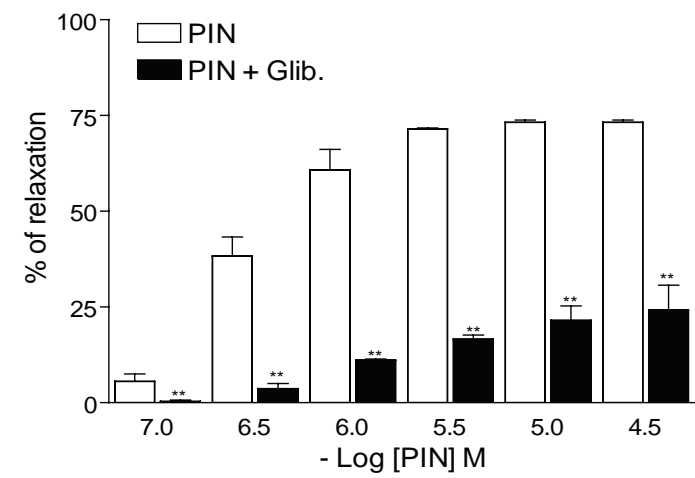

Figure 3. Effect of glibenclamide (GLIB) $\left(10^{-6} \mathrm{M}\right)$ on: (A) - the relaxation induced by aqueous extract of E. vellutina (AE) (0.05, $0.15,0.5$ and $1.5 \mathrm{mg} / \mathrm{mL}$ ) and (B) - by pinacidil (PIN) $\left(10^{-8}-10^{-5} \mathrm{M}\right)$ during the electrical field stimulation of the rat vas deferens. The values are expressed as mean \pm s.e.mean of six experiments. ${ }^{* *} \mathrm{p}<0.01$ vs AE or PIN.

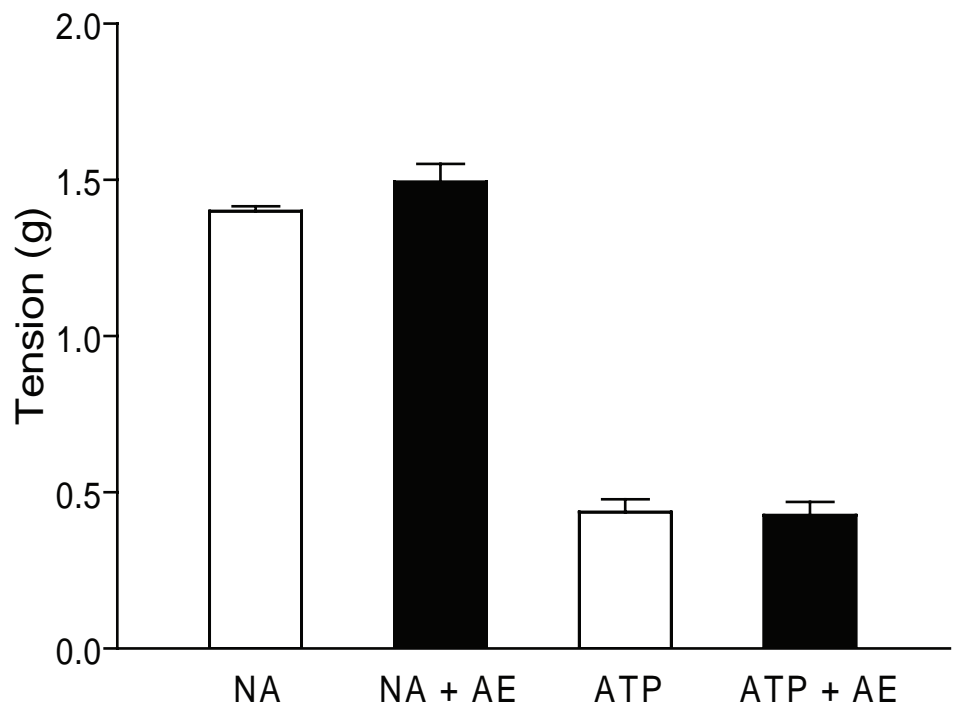

Figure 4. Effect of the aqueous extract of E. vellutina $(\mathrm{AE})(0.15 \mathrm{mg} / \mathrm{mL})$ on the noradrenaline (NA) $\left(10^{-5} \mathrm{M}\right)$ and ATP $\left(10^{-4} \mathrm{M}\right)$ induced contractions of the rat vas deferens. The values are expressed as mean \pm s.e.mean of six experiments.

involvement of $\mathrm{K}^{+}$channels in the inhibitory effect of the AE. The vas deferens was incubated, in the presence of $1.5 \mathrm{mg} / \mathrm{mL}$ of the $\mathrm{AE}$, with antagonists for some known subtypes of $\mathrm{K}^{+}$channels: tetraethylamonium $\left(10^{-6} \mathrm{M}\right)$, for $\mathrm{Ca}^{2+}$-dependent $\mathrm{K}^{+}$channels (Latorre et al., 1989), 4-aminopyridine $\left(10^{-6} \mathrm{M}\right)$ for the delayed rectifier and A type $\mathrm{K}^{+}$channels (Thompson, 1977), and glibenclamide $\left(10^{-6} \mathrm{M}\right)$ for the ATP-dependent $\mathrm{K}^{+}$ channels (Kalei et al., 1985). As showed in Figure 2B, only glibenclamide interfered with the effect of the EA $(p<0.01, n=6)$, suggesting a possible involvement of ATP-dependent $\mathrm{K}^{+}$channels in the relaxant effects of the
AE. In order to confirm this hypothesis, we performed a concentration-response curve to $\mathrm{AE}(0.05,0.15,0.5$ and $1.5 \mathrm{mg} / \mathrm{mL}$ ) during the electrical field stimulation of the rat vas deferens in the absence and presence of glibenclamide $\left(10^{-6} \mathrm{M}\right)$. In this condition, AE induced relaxation which was attenuated by glibenclamide in all concentrations (Figure 3A). Similarly, pinacidil $\left(10^{-8}\right.$ $3.10^{-6} \mathrm{M}$ ), a specific agonist for the ATP-dependent $\mathrm{K}^{+}$ channels (Grana et al., 1997), also induced relaxation which was also inhibited by glibenclamide $\left(10^{-6} \mathrm{M}\right)$ (p $<0.01 ; \mathrm{n}=6$ ) (Figure 3B). These results demonstrated that, at least in part, ATP-dependent $\mathrm{K}^{+}$channels play 


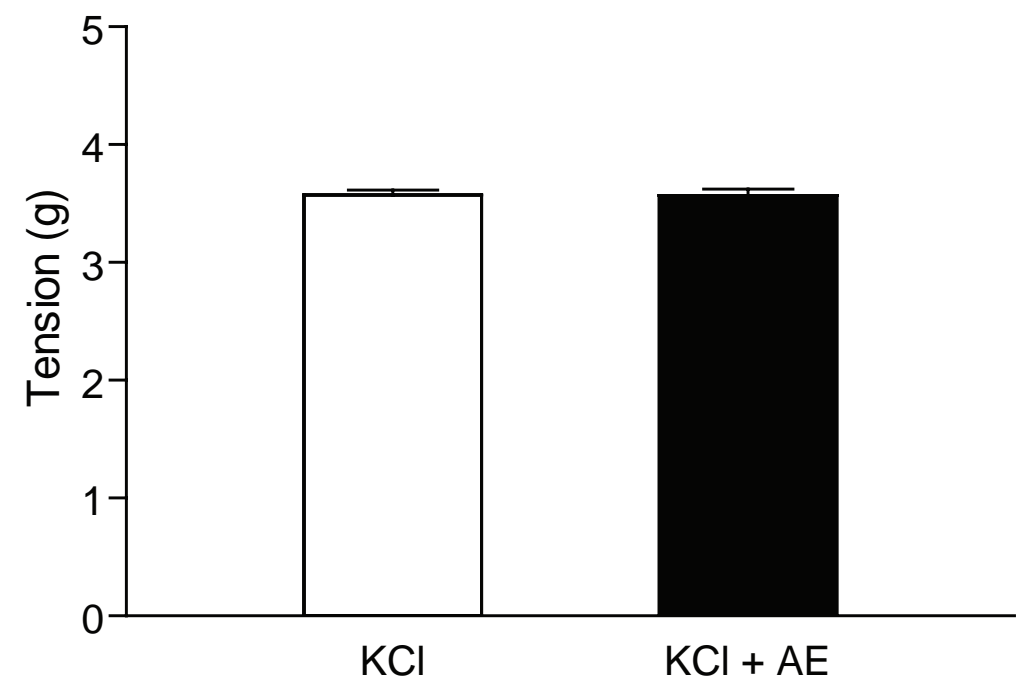

Figure 5. Effect of the aqueous extract of E. vellutina (AE) $(0.15 \mathrm{mg} / \mathrm{mL})$ on the $\mathrm{KCl}(80 \mathrm{mM})$ induced contractions of the rat vas deferens. The values are expressed as mean \pm s.e.mean of six experiments.

important role in the AE-induced relaxant effect. (Figure $2 \mathrm{~A}$ and $\mathrm{B})$

The specific interaction of the $\mathrm{AE}$ with ATP-dependent $\mathrm{K}^{+}$channels suggests a possible presynaptic modulation of the extract, since it was recently demonstrated that this subtype of $\mathrm{K}^{+}$channel causes vas deferens relaxation by inhibiting ATP release from the nerve endings of adrenergic terminals (Grana et al., 1997). (Figure 3A and B)

The co-transmission of noradrenaline and ATP is well established for the rat vas deferens (French; Scott, 1983; Sneddon; Burnstock, 1984). Thus, in order to check a possible post-synaptic action of the $\mathrm{AE}$, the vas deferens were contracted by application of noradrenaline (NA) $\left(10^{-5} \mathrm{M}\right)$ or ATP $\left(10^{-4} \mathrm{M}\right)$ without electrical stimulation and in the absence and presence of $\mathrm{AE}(0.15 \mathrm{mg} / \mathrm{mL})$. As showed in Figure 4 the AE did not alter the NA and ATP induced contractions (n $=6)$. Finally, we tested the effects of the AE on the contraction induced by $\mathrm{KCl}(80 \mathrm{mM})$. As is clear from Figure 5, the AE did not interfere with the contraction induced by $\mathrm{KCl}$ depolarisation ( $\mathrm{p}>0.05 ; \mathrm{n}=6)$ ). (Figure 4 and Figure 5).

Taken together, the data described above suggests that the inhibition of the electrically driven muscle twitches by the AE is probably due to a presynaptic interaction of the extract with ATP-dependent $\mathrm{K}^{+}$channel from vas deferens sympathetic neurons.

\section{AKNOWLEDGEMENTS}

The authors wish to thank Dr. Carlos Dias Jr., for the taxonomic identification of Erythrina vellutina. This work was supported by grants from CNPq (Brazil) and FAPITEC/SE (Brazil).

\section{REFERENCES}

Agra MF, França PF, Barbosa-Filho JM 2007. Synopsis of the plants known as medicinal and poisonous in Northeast of Brazil. Rev Bras Farmacogn 17: 114140.

Brown DA, Docherty JR, French AM, McDonald A, McGrath JC, Scott NC 1983. Separation of adrenergic and nonadrenergic contractions to field stimulation in the rat vas deferens. B. J Pharmacol 79: 379-393.

Carneiro RP, Markus RP 1990. Presynaptic nicotinic receptors involved in release of noradrenaline and ATP from the prostatic portion of the rat vas deferens. $J$ Pharmacol Exp Ther 255: 95-100.

Dantas MC, Oliveira FS, Bandeira SM, Batista JS, Silva Jr, CD, Alves PB, Antoniolli AR, Marchioro M 2004. Central nervous system effects of the crude extract of Erythrina velutina on rodents. J Ethnopharmacol 94: 129-133.

El-Olemy MM, Ali AA, El-Mottaleb MA 1983. Erythrina alkaloids. I. The alkaloids of the flowers and seeds of Erythrina variegata. Lloydia 41: 342-347.

French AM, Scott NC 1983. Evidence to support the hypothesis that ATP is a co-transmitter in the rat vas deferens. Experientia 39: 264-266.

Garín-Aguilar MA, Luna JER, Soto-Hernández M, Del Toro V, Vázquez MM 2000. Effect of crude extracts of Erythrina americana Milld on aggressive behavior in rats. J Ethnopharmacol 69: 189-196.

Grana E, Boselli C, Bianchi L 1997. Cromakalim blocks the purinergic response evoked in rat vas deferens by single-pulse electrical stimulation. Eur J Pharmacol 319: 57-64.

Hegde VR, Dai P, Patel MG, Puar MS, Das P, Pai J, Bryant R, Cox PA 1997. Phospholipase $A_{2}$ inhibitors from an Erythrina species from Samoa. J Nat Prod 60: 537539.

Kalei M, Noda A, Shibasaki T 1985. Properties of adenosine- 
triphosphate-regulated potassium channels in guinea pig ventricular cells. J Physiol (Lond) 363: 441-462.

Knoll J, Somogyi GT, Illés P, Vizi ES 1972. Acetylcholine release from isolated vas deferens of the rat. $N$-S Arch Pharmacol 274: 198-203.

Kòbaiashi M, Mahmud T, Yoshioka N, Shibuya H, Kitagawa I 1997. Indonesian medicinal plants. XXI. Inhibitors of $\mathrm{Na}^{+} / \mathrm{K}^{+}$exchanger from the bark of Erythrina variegata and the roots of Maclura cochinchinensis. Chem Pharm Bull 45: 1615-1619.

Latorre R, Oberhauser A, Labarca P, Alvarez O 1989. Varieties of calcium-activated potassium channels. Annu Rev Physiol 51: 385-399.

Matos FJA 1997. O formulário fitoterápico do Professor Dias da Rocha. In: C.E. Fortaleza, Editor (2a ed.), Universidade Federal do Ceará Edições.

Ribeiro MD, Onusic GM, Poltronieri SC, Viana MB 2006. Effect of Erythrina velutina and Erythrina mulungu in rats submitted to animal models of anxiety and depression. Braz J Med Biol Res 39: 263-270.

Sneddon P, Burnstock G 1984. Inhibition of excitatory junction potentials in guinea pig vas deferens by $\alpha \beta$ methylene ATP: further evidence for ATP and noradrenaline as co-transmitters. Eur J Pharmacol 100: 85-90.

Sneddon P, Westfall DP, Fedan JS 1982. Co-transmitters in the motor nerves of the guinea-pig vas deferens: elctrophysiological evidence. Science 218: 693-695.

Telikepalli H, Gollapudi SR, Keshevarz-Shokri A, Velazquez L, Sandmann RA, Veliz EA, Rao KVJ, Madhavi AS, Mitscher L 1990. Isoflavonoids and a cinnamyl phenol from root extracts of Erythrina variegat. Phytochemestry. 29: 2005-2007.

Teske M, Trentini AMM 1995. Herbarium: compêndio de fitoterapia, Herbarium Laboratório Botânico, Curitiba - PR.

Thompson SH 1997. Three pharmacological distinct potassium channels in molluscan neurones. $J$ Physiol (Lond) 265: 465-488.

Vasconcelos SM, Macedo DS, Melo CT, Paiva Monteiro A, Rodrigues AC, Silveira ER, Cunha GM, Sousa FC, Viana GS 2004. Central activity of hydroalcoholic extracts from Erythrina velutina and Erythrina mulungu in mice. J Pharm Pharmacol 56: 389-393.

Vasconcelos SM, Oliveira GR, Carvalho MM, Rodrigues AC, Silveira ER, Fonteles MMF, Sousa FCF, Viana GSB 2003. Antinociceptive activities of the hydroalcoholic extract from Erythrina velutina and Erythrina mulungu in mice. Biol Pharm Bull 26: 946-949.

Virtuoso S, Davet A, Dias JFG, Cunico MM, Miguel MD, Oliveira AB, Miguel OG 2005. Estudo preliminar da atividade antibacteriana das cascas de Erythrina velutina Willd., Fabaceae (Leguminosae). Rev Bras Farmacogn 15: 147-142. 